\title{
Anisakis simplex (s.s.) larvae in wild Alaska salmon: no indication of post-mortem migration from viscera into flesh
}

\author{
Horst Karl ${ }^{1, *}$, Florian Baumann ${ }^{2}$, Ute Ostermeyer ${ }^{1}$, Thomas Kuhn ${ }^{3}$, Sven Klimpel ${ }^{3}$ \\ ${ }^{1}$ Department of Safety and Quality of Milk and Fish Products, Federal Research Institute for Nutrition and Food, \\ Max Rubner-Institut, Palmaille 9, 22767 Hamburg, Germany \\ ${ }^{2}$ Qualitätssicherung, Frozen Fish International GmbH, Am Lunedeich 115, 27572 Bremerhaven, Germany \\ ${ }^{3}$ Biodiversity and Climate Research Centre (BiK-F), Institute for Ecology, Evolution \& Diversity, Goethe University, \\ Georg-Voigt-Str. 14-16, 60325 Frankfurt am Main, Germany
}

\begin{abstract}
The prevalence, mean intensity and distribution of Anisakis nematode third-stage larvae (L3) in the muscle and viscera of wild-caught chum salmon Oncorhynchus keta, pink salmon $O$. gorbuscha and sockeye salmon $O$. nerka were compared immediately after catch. Salmon were collected during the fishing season in July 2007 in Bristol Bay and Prince William Sound close to Cordova, Alaska (USA). All fish were infected, and more than $90 \%$ of the nematode larvae were found in the edible muscle meat. The isolated anisakid L3 were genetically identified as A. simplex (s.s.). The distribution of nematodes in the muscle meat of fresh-caught salmon was examined in $49 \mathrm{O}$. keta, 50 O. nerka and 12 O. gorbuscha from Cordova. Most of the larvae were detected in the muscle parts around the body cavity, but nematodes were also found in the tail meat and epaxial muscle (loins). The mean intensity of Anisakis larvae in the edible part was 21 individuals for $O$. gorbuscha, 62 individuals for $O$. keta and 63 individuals for $O$. nerka. No difference in the intensity of Anisakis larvae in the hypaxial muscle was found between fresh-caught and immediately gutted salmon and individuals stored ungutted for $24 \mathrm{~h}$ either on ice or in refrigerated sea water.
\end{abstract}

KEY WORDS: Pacific salmon · Anisakis simplex (s.s.) $\cdot$ Muscle meat $\cdot$ Refrigerated sea water (RSW) storage $\cdot$ Onchorhynchus keta $\cdot$ O. nerka $\cdot$ O. gorbuscha

\section{INTRODUCTION}

The presence of Anisakis spp. and other nematode larvae of health significance in fish as seafood has been recognised for a long time (Agersborg 1918, Kahl 1936). Live nematodes, when ingested in raw, not adequately processed or undercooked fish can cause anisakidosis.

Species of the nematode genus Anisakis are globally distributed fish parasites and typically infect cetaceans or pinnipeds as final hosts. This genus previously included only 3 species (Davey 1971). Beside readily described morphospecies (A. physeteris, A. simplex, A. typica), the analyses of allozymes, PCR-RFLPs of rDNA and mtDNA cox-2 data have revealed that this genus currently includes 9 distinct species: A. simplex (s.s.), A. pegreffii and A. simplex $\mathrm{C}$ (representing the $A$. simplex-complex), together with $A$. typica, $A$. nascettii and A. ziphidarum; and A. paggiae, A. brevispiculata, and A. physeteris representing the A. physeteris-complex (e.g. Valentini et al. 2006, Klimpel et al. 2008, 2010, Mattiucci \& Nascetti 2008, Mattiucci et al. 2009). All of these species are morphologically very similar but genetically distinct and have specific host preferences, life cycles and zoogeographical distributions (Valentini et al. 2006, Kellermanns et al. 2007, Klimpel et al. 2007, Mattiucci et al. 2007, Mattiucci \& Nascetti 2008).

In general, the life cycle of Anisakis proceeds in several steps and has been studied and described in detail by several authors (e.g. Grabda 1991, Klimpel et al. 
2004, 2008). Anisakis is taken up by marine fish via food. After ingestion of infested intermediate hosts by the live fish, Anisakis larvae penetrate the intestinal wall. Most larvae coil up on the surface of the internal organs but some migrate into the flesh. Several investigations have shown that Anisakis larvae are regularly present in the flesh of marine teleost fish immediately after death (Davey 1972, Smith 1984, Højgaard 1995, Karl \& Leinemann 1995). However, there is some controversy as to whether migration takes place from the viscera into the flesh during the post-mortem storage of fish.

Roepstorff et al. (1993) studied the effect of modern handling practices such as storage in refrigerated seawater (RSW) of fat and lean herring Clupea harengus. They did not find any indication of Anisakis larvae migrating from the belly cavity into the surrounding flesh. This concurred with the results of earlier studies in lean fish species stored on ice such as whiting Merlangius merlangus and blue whiting Micromesistius poutassou (Smith 1984), and Alaska pollock Theragra chalcogramma (Arthur et al. 1982). In mackerel Scomber scombrus, Smith (1984) showed a migration into the flesh from the viscera. These studies and recent investigations (Karl 2008) on North Atlantic marine fish species showed that between 90 and $98 \%$ of the Anisakis larvae are situated in the belly cavity and the visceral organs at the time of catch and only few are embedded in the surrounding tissue of the peritoneal cavity (belly flaps). One exception seems to be maturing Pacific salmon. Sugawara et al. (2004) found a higher abundance of A. simplex s.l. in the muscle of chum salmon Oncorhynchus keta, and Deardorff \& Kent (1989) recovered $87 \%$ of $A$. simplex s.l. from the edible musculature of wild caught sockeye salmon $O$. nerka.

A high increase of parasite infection was observed by Urawa \& Fujisaki (2006) in adult Oncorhynchus keta between 2002 and 2006. The abundance was less than 20 parasites fish ${ }^{-1}$ in 2002 and reached 160 parasites fish ${ }^{-1}$ in 2006. Similar findings were observed by Etzel \& Ramdohr (2006), who investigated cold smoked Pacific salmon fillets and slices on the German market. Aware of the increasing abundance of Anisakis larvae in German wild salmon products, a comprehensive study was initiated by the German fish industry in close cooperation with the Max Rubner-Institut to monitor the actual situation in wild salmon. The study focused on wild salmon from Alaska (USA), because most of the raw wild salmon of interest for the German fish industry is delivered as headed and gutted deepfrozen fish from various fishing areas of the state of Alaska, the Russian Federation and Canada.

Our objective was to analyse the prevalence, abundance and distribution of Anisakis larvae in the muscle and viscera of wild-caught Oncorhynchus keta, O. gor- buscha and O. nerka, collected from different fishing areas of Alaska immediately after catch. We also discuss the possible influence of delayed gutting under typical handling practices such as storage of whole salmon for $24 \mathrm{~h}$ in RSW as well as the alternative storage on wet ice.

\section{MATERIALS AND METHODS}

Sample collection. Salmon samples were collected during their migratory spawning run within $1 \mathrm{wk}$ in July 2007 at 2 locations (Nushagak and Naknek district) of the Bristol Bay area and at the Prince William Sound close to Cordova in Alaska. Fresh-caught sockeye Oncorhynchus nerka, chum O. keta and pink salmon O. gorbuscha from Cordova were measured for total length and immediately gutted after catch on board the respective trawler. The viscera (intestines and all visceral organs) and the gutted fish were separately packed into plastic bags and deep frozen. Detailed data on the samples are compiled in Table 1. To study the effect of delayed gutting, salmon of the same catch were stored ungutted as whole fish on board tenders either on flake ice in covered ice boxes or in RSW tanks (capacity 20 to 25 t) under commercial conditions. After $24 \mathrm{~h}$, all stored samples were gutted, the fish were cut with a sharp knife along the lateral line into 2 halves, the hypaxial muscle parts (belly flaps) and viscera were packed into separate plastic bags and deep frozen. If migration of Anisakis larvae from the viscera occurs, they will preferably move into the surrounding muscle tissue of the body cavity resulting in a higher abundance of Anisakis in the belly flaps. Taking this and also the high transport costs to Europe into account, it was decided for this part of the study to collect only the hypaxial muscle below the lateral line and the corresponding visceral organs. The same procedure was applied to freshcaught samples from the Nushagak and the Naknek district. All samples were deep frozen and shipped by container to Europe and reached the laboratory deep frozen in December 2007. Samples were stored at $-24^{\circ} \mathrm{C}$ until analysis.

Sample preparation. Fish or hypaxial musculature and the corresponding viscera were thawed. The gonads were separated from the viscera and deep frozen again. The remaining organs were digested by means of pepsin/HCl (see next subsection). Gutted whole fish were washed, drained, weighed and filleted by hand, taking care to preserve the complete belly flaps and the costal bones intact. Approximately $1 \mathrm{~cm}$ of the lower part of the belly flaps (fat edges) were removed, and the trimmed fillets were skinned. Each fillet was weighed and divided into several parts: 
Table 1. Oncorhynchus spp. Origin, description of samples and sample sizes of the 3 species of Pacific salmon studied. Length and weight data given as mean (range). Fillet weight is that of a single fillet, including belly flap and without skin; weight of belly flaps represents both flaps without skin. RSW: refrigerated sea water; nd: not determined

\begin{tabular}{|c|c|c|c|c|c|c|c|}
\hline $\begin{array}{l}\text { Fishing } \\
\text { ground }\end{array}$ & Storage & Sample & $\begin{array}{c}\text { No. of } \\
\text { samples }\end{array}$ & $\begin{array}{l}\text { Length } \\
\text { (cm) }\end{array}$ & $\begin{array}{l}\text { Weight } \\
\text { (g) }\end{array}$ & $\begin{array}{l}\text { Fillet weight } \\
\text { (g) }\end{array}$ & $\begin{array}{c}\text { Weight of } \\
\text { belly flaps (g) }\end{array}$ \\
\hline \multicolumn{8}{|c|}{ Chum salmon $O$. keta } \\
\hline Cordova & Fresh-caught & Whole fish gutted & 49 & $63(58-70)$ & $2253(1600-3110)$ & $595(398-793)$ & $357(230-515)$ \\
\hline Cordova & $24 \mathrm{~h}$ ice & Hypaxial muscle & 23 & nd & nd & nd & $430(298-600)$ \\
\hline Cordova & 24h RSW & Hypaxial muscle & 50 & nd & nd & nd & $426(300-605)$ \\
\hline Nushagak district & Fresh-caught & Hypaxial muscle & 26 & nd & nd & nd & $432(225-591)$ \\
\hline \multicolumn{8}{|c|}{ Pink salmon $O$. gorbuscha } \\
\hline Cordova & Fresh-caught & Whole fish gutted & 12 & $54(49-64)$ & $1711(1120-2670)$ & $450(281-660)$ & $268(178-408)$ \\
\hline Cordova & $24 \mathrm{~h}$ ice & Hypaxial muscle & 14 & nd & nd & nd & $302(221-410)$ \\
\hline \multicolumn{8}{|c|}{ Sockeye salmon $O$. nerka } \\
\hline Cordova & Fresh-caught & Whole fish gutted & 50 & $60(52-67)$ & $2219(1530-3300)$ & $641(414-986)$ & $376(246-618)$ \\
\hline Cordova & $24 \mathrm{~h}$ ice & Hypaxial muscle & 49 & nd & nd & nd & $502(322-897)$ \\
\hline Cordova & 24 h RSW & Hypaxial muscle & 50 & nd & nd & nd & $465(261-686)$ \\
\hline Nushagak district & Fresh-caught & Hypaxial muscle & 25 & nd & nd & nd & 390 (226-689) \\
\hline Naknek district & Fresh-caught & Hypaxial muscle & 25 & nd & nd & nd & $420(187-663)$ \\
\hline
\end{tabular}

upper and lower epaxial muscle, tail muscle and belly flap. The belly flap was further divided into upper part, lower part and tail part. A detailed drawing is given in Fig. 1. All parts were separately analysed for nematodes applying the UV-press method (Karl \& Leinemann 1993) as described below. The viscera samples of the storage experiments were prepared and analysed as described above. The hypaxial muscle sample was split into left and right part, skinned and trimmed in a way to obtain belly flaps comparable to those of the whole gutted fish. Further treatment followed the same protocol as described above.

Detection of nematodes. Nematodes were detected by using the digestion- and the UV-press method. For the digestion method, the viscera were digested by the pepsin- $\mathrm{HCl}$ process as described in detail in the CODEX standard for salted Atlantic herring and salted sprat in Annex Ia (CODEX STAN 244 2004). The solution was decanted through a sieve, and the contents of the sieve were examined for nematode larvae.

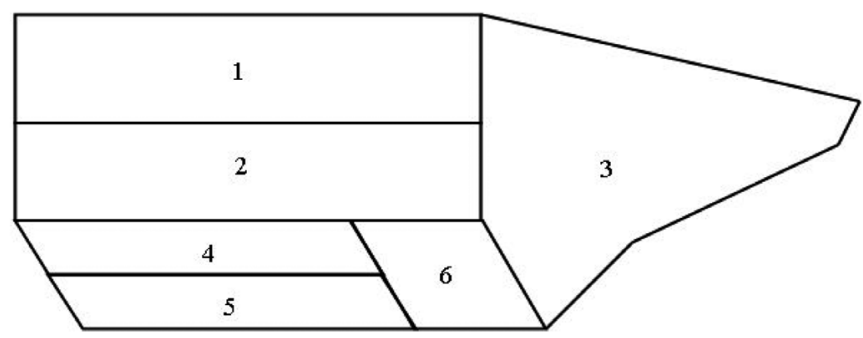

Fig. 1. Oncorhynchus spp. Subdivision of trimmed freshcaught Alaska salmon fillets to study the distribution of Anisakis larvae. 1: upper epaxial muscle; 2: lower epaxial muscle; 3 : tail muscle; 4 : upper belly flap; 5 : lower belly flap; 6: belly flap tail part
The UV-press method was described in detail by Karl \& Leinemann (1993). In brief, the fillet parts were pressed in plastic bags to thin layers of 1 to $2 \mathrm{~mm}$ by means of an automatic press (holding time $20 \mathrm{~s}$ at 8 bar) and examined under UV light. Deep-frozen nematode larvae show fluorescence under UV light $(366 \mathrm{~nm})$ and can be counted visually. The method also allows a differentiation of Anisakis, Pseudoterranova and Hysterothylacium larvae at genus level due to their different appearance under UV-light (Levsen \& Lunestad 2010).

To ensure that the data from the digestion and UVpress procedure were suitable for comparison, various samples of Oncorhynchus gorbuscha, O. keta and $O$. nerka fillet parts were first examined by the UVpress method and later digested. The results showed excellent agreement in the number of nematodes detected.

Nematode species identification. Anisakis larvae were macroscopically identified by their more or less bright light blue fluorescence and typical appearance under UV light. Various subsamples of anisakid larvae were isolated from the flesh and identified by light microscopy following the morphological criteria proposed by Berland (2003).

Genetic identification was performed on 45 individual Anisakis larvae, which could be isolated undamaged from the pressed fillets. Genomic DNA was extracted and purified from each of 10 Anisakis larvae randomly taken from the meat of Oncorhynchus nerka and O. keta of both sampling areas (Bristol Bay and Cordova) as well as 5 individuals from the flesh of $O$. gorbuscha (Cordova) using the PeqGOLD genomic DNA extraction kit (Peqlab Biotechnology) according 
to the manufacturer's instructions. The rDNA region comprising the ITS-1, 5.8S, ITS-2 and flanking sequences (=ITS+) was amplified using the primers NC2 (5'-TTA GTT TCT TTT CCT CCG CT-3') and TK1 (5'GGC AAA AGT CGT AAC AAG GT-3'; Zhu et al. 2000, Kuhn 2010). The PCR-reaction (50 $\mu$ l) included $25 \mu$ of Master-Mix (Peqlab) containing dNTPs, $\mathrm{MgCl}_{2}$, buffer and Taq polymerase, $3 \mu \mathrm{l}$ of each primer, $14 \mu$ double distilled $\mathrm{H}_{2} \mathrm{O}$ and $5 \mu$ genomic DNA. Each PCR reaction was performed in a thermocycler (Peqlab) under the following conditions: initial denaturation at $95^{\circ} \mathrm{C}$ for $1 \mathrm{~min}, 40$ cycles of $94^{\circ} \mathrm{C}$ for $45 \mathrm{~s}$ (denaturation), $55^{\circ} \mathrm{C}$ for $45 \mathrm{~s}$ (annealing) and $72^{\circ} \mathrm{C}$ for $45 \mathrm{~s}$ (extension), followed by a final extension at $72^{\circ} \mathrm{C}$ for 10 min. Samples without DNA were included in each PCR run. PCR products were examined on $1 \%$ agarose gels. A 100 bp ladder marker (Peqlab) was used to estimate the size of the PCR products. To identify the anisakid nematodes, the PCR products were purified with PeqGOLD Cycle-Pure Kit (Peqlab). Afterwards a total volume of $7 \mu \mathrm{l}$, including $2 \mu \mathrm{l}$ primer (individually) and $5 \mu \mathrm{l}$ of the PCR product $\left(250 \mathrm{ng} \mathrm{ll}^{-1}\right)$ were sequenced by Seqlab GmbH (Goettingen, Germany).

Data analysis. A Mann-Whitney rank sum test was used to test possible differences in larvae intensities in the hypaxial muscle of sockeye and chum salmon from different fishing grounds and to compare the intensity in fresh and chilled stored Pacific salmon. To describe the parasite infection data, the terms prevalence, intensity and abundance are used following Bush et al. (1997) and Rózsa et al. (2000).

\section{RESULTS AND DISCUSSION}

\section{Anisakis larvae in different fresh-caught salmon species from Alaska}

During their spawning migration in the Prince William Sound close to Cordova, 50 Oncorhynchus nerka and 49 O. keta were randomly taken from commercial catches on board trawlers. Only 12 individuals of O. gorbuscha could be collected. Size, weight and appearance were typical for the raw material used by the German fish industry for wild salmon products (Table 1). The fish were gutted directly after catch to prevent a possible post-mortem migration of nematodes. The infection levels, summarised in Table 2, reflect the situation in live salmon from this area at capture. All salmon of each species from the Cordova area were infected with anisakid larvae (prevalence = $100 \%$ ), and more than $90 \%$ of the larvae were found in the muscle meat (edible part). Virtually all larvae were macroscopically and morphologically identified as Anisakis simplex. The flesh of O. nerka and O. keta was heavily infected, with a mean intensity of 62 and 63 larvae, respectively. O. gorbuscha was less infected, with a mean intensity of 21 individuals in the flesh.

Fig. 2 shows the frequency distribution of Anisakis larvae in the edible muscle meat of the 3 Pacific salmon species and demonstrates the large variation of the infection levels observed between the individuals of each host salmon species. The number of nematode larvae varied between a minimum of 5 and a maximum

Table 2. Anisakis sp. infecting Oncorhynchus spp. Infection parameters in 3 species of fresh-caught wild salmon from Cordova, Alaska (USA). Data of the intensity, abundance and the number of nematodes $\mathrm{kg}^{-1}$ are given as mean (range). Fillet indicates a single fillet without belly flap; belly flap represents a single belly flap. na: not applicable

\begin{tabular}{|c|c|c|c|c|c|}
\hline Infection parameter & Whole fish & Flesh & Viscera & Fillet & Belly flap \\
\hline \multicolumn{6}{|l|}{$O$. keta $(n=49)$} \\
\hline Prevalence (\%) & 100 & 100 & 74 & 93 & 100 \\
\hline Intensity & $65.3(9-301)$ & $63.2(8-297)$ & $2.8(1-16)$ & $6.2(1-36)$ & $25.9(2-131)$ \\
\hline Abundance & $65.3(9-301)$ & $63.2(8-297)$ & $2.1(0-16)$ & $5.7(0-36)$ & $25.9(2-131)$ \\
\hline Nematodes $\mathrm{kg}^{-1}$ & na & $56(4-328)$ & na & $15(0-107)$ & $152(11-936)$ \\
\hline Relative frequency (\%) & na & 95 & 5 & na & na \\
\hline \multicolumn{6}{|l|}{ O. gorbuscha $(\mathrm{n}=12)$} \\
\hline Prevalence (\%) & 100 & 100 & 67 & 67 & 100 \\
\hline Intensity & $23.5(5-43)$ & $21.4(5-41)$ & $3.1(1-5)$ & $2.6(1-7)$ & $8.5(2-20)$ \\
\hline Abundance & $23.5(5-43)$ & $21.4(5-41)$ & $2.1(0-5)$ & $1.7(0-7)$ & $8.5(2-20)$ \\
\hline Nematodes $\mathrm{kg}^{-1}$ & na & $23(3-59)$ & na & $5(0-18)$ & $65(9-177)$ \\
\hline Relative frequency (\%) & na & 91 & 9 & na & na \\
\hline \multicolumn{6}{|l|}{ O. nerka $(\mathrm{n}=50)$} \\
\hline Prevalence (\%) & 100 & 100 & 72 & 95 & 100 \\
\hline Intensity & $63.7(13-175)$ & $61.5(12-165)$ & $3.1(1-32)$ & $4.6(1-17)$ & $26.4(3-88)$ \\
\hline Abundance & $63.7(13-175)$ & $61.5(12-165)$ & $2.2(0-32)$ & $4.3(0-17)$ & $26.4(3-88)$ \\
\hline Nematodes $\mathrm{kg}^{-1}$ & na & $48(5-179)$ & na & $9(0-34)$ & $142(13-528)$ \\
\hline Relative frequency (\%) & na & 96 & 4 & na & na \\
\hline
\end{tabular}


of 41 nematodes in the flesh of Oncorhynchus gorbuscha, between 8 and 297 nematodes in O. keta and between 12 and 165 nematodes in O. nerka.

The results are in accordance with the very high infection levels reported by Urawa \& Fujisaki (2006) for the muscle meat of Oncorhynchus keta returning to the Chitose River, Japan.

Sugawara et al. (2004) reported that immature Oncorhynchus keta caught in the open ocean had the same distribution pattern, with Anisakis simplex larvae being most abundant in the muscles. Our data show that the high intensity of nematodes in the muscle seems to be an attribute related not only to O. keta but also to other Pacific salmon species. This is in contrast to most other marine fish species, where parasites infect mainly the body cavity and the visceral organs (Strømnes \& Andersen 1998).

\section{Infection sites}

To study the distribution of nematodes in the flesh of fresh-caught Pacific salmon, the fillets, including belly flaps, of each fish were divided into several parts according to Fig. 1 and analysed. Table 3 gives the average percentage of the Anisakis larvae in each compartment. All 3 fish species showed a comparable distribution pattern of the larvae. Approximately $80 \%$ of the Anisakis larvae were found in the belly flap area (positions 4, 5, 6; Fig. 1), and the larvae were more or less equally distributed within the belly flap. A slightly different picture was observed in the epaxial muscle. The upper parts (position 1) of the Oncorhynchus nerka and $O$. keta fillets were less infected than the lower epaxial muscle (position 2) and the tail parts (position 3). In the case of O. gorbuscha, the small sample size did not allow a reliable comparison. Our data are in excellent agreement with the distribution pattern in fillets of adult $O$. keta returning to the Chitose River, as reported by Sugawara et al. (2004).

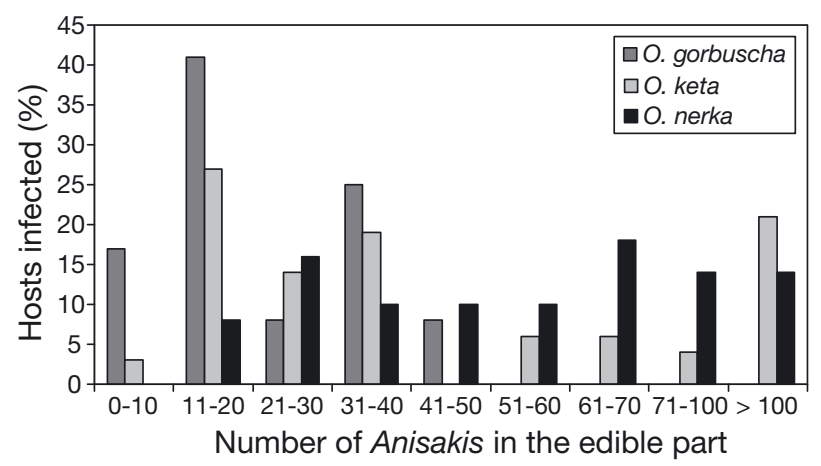

Fig. 2. Anisakis sp. infecting Oncorhynchus spp. Frequency distribution of Anisakis larvae in the edible part of 3 Pacific salmon species from Cordova, Alaska (USA)

\section{Reduction of Anisakis infestation in fillets}

Removal of the belly flaps

The high levels of Anisakis larvae in wild salmon fillets led to a discussion of technological measures to reduce the number of nematodes. The removal of the complete belly flap in a 'jumbo cut' (Priebe 2007) resulted in a considerable reduction of Anisakis larvae in the Pacific salmon fillets studied (Table 2). The mean intensity of nematodes in the remaining Oncorhynchus gorbuscha, O. keta and O. nerka fillets dropped to 2.6, 4.6 and 6.2, respectively, but the infection levels of single fillets without belly flaps were still high due to the large variation of the infection intensity, e.g. ranging between 1 and 36 larvae per chum salmon fillet. The removal of the belly flap also led to a considerable weight loss of approximately $30 \%$.

Etzel et al. (2007) proposed to establish an allowable limit of 20 nematodes $\mathrm{kg}^{-1}$ wild salmon fillet product in Germany. In Table 2, the infection levels are also calculated as number of nematodes $\mathrm{kg}^{-1}$. The data show that the average number of nematodes $\mathrm{kg}^{-1}$ in the fillets remained below the proposed limit after complete removal of the belly flaps, but according to our data, more than $20 \%$ of the chum salmon and approximately $8 \%$ of the sockeye salmon fillets from Cordova still exceeded the proposed limit (Fig. 3).

\section{Selection of sizes}

Within the length range of 52 to $67 \mathrm{~cm}$ for Oncorhynchus nerka and 58 to $70 \mathrm{~cm}$ for O. keta, no relationship was found between the number of Anisakis larvae and fish body size $(O$. nerka: $\mathrm{r}=0.245$; O. keta: $r=0.07$; Fig. 4). The results correspond to the results of Sugawara et al. (2004), who found no correlation between length and infection intensity for adult $O$. keta salmon returning to the Chitose River. Thus the

Table 3. Anisakis sp. infecting Oncorhynchus spp. Average distribution $(\%)$ of larvae in the flesh of fresh-caught wild Alaska salmon species. Positions 1 to 6 correspond to those shown in Fig. 1

\begin{tabular}{|lccc|}
\hline Position & O. keta & O. gorbuscha & O. nerka \\
\hline $\begin{array}{l}\text { Epaxial muscle } \\
\text { 1. Upper part }\end{array}$ & 3.1 & 7.7 & \\
2. Lower part & 6.2 & 7.7 & 6.2 \\
3. Tail & 9.4 & 7.7 & 6.5 \\
Belly flap & & & \\
4. Upper part & 28.1 & 30.8 & 29.0 \\
5. Lower part & 28.1 & 23.0 & 35.5 \\
6. Tail part & 25.1 & 23.0 & 19.4 \\
\hline
\end{tabular}


selection of certain size classes cannot be used as a measure to reduce nematode abundance in the edible part.

\section{Genetic anisakid nematode species identification}

The ITS-1, 5.8S and ITS-2 sequences were determined for 45 Anisakis nematodes isolated from the 3 studied Oncorhynchus species. The sequences obtained were compared with those previously deposited for the same marker in GenBank using BLASTX. The length of the PCR product including the 3 regions ITS-1, 5.8S and ITS-2 was $857 \mathrm{bp}$, while the length of the ITS-1 and ITS-2 sequences of $A$. simplex (s.s.) was 392 and $308 \mathrm{bp}$, respectively. The $5.8 \mathrm{~S}$ sequences were all $157 \mathrm{bp}$ long. The $\mathrm{G}+\mathrm{C}$ contents of all sequences were $46.68 \%$ (ITS-1), 51.59\% (5.8S) and $42.21 \%$ (ITS2). The obtained sequences of $A$. simplex (s.s.) from the 3 fish species O. gorbuscha, O. keta and O. nerka (GenBank accession numbers GU735486, GU735487, GU735488, GU735489 and GU735490, respectively) were identical to a sequence already isolated from the sibling species $A$. simplex (s.s.) from the macrourid Trachyrincus scabrus (EU718471.1). A. simplex (s.s.) is a typical parasite of cetaceans of the families Delphinidae, Monodontidae, Phocoenidae and Balaenopteridae and has been genetically identified mainly in the North Atlantic and Pacific Oceans (e.g. Mattiucci \& Nascetti 2008). Species of these cetacean families constitute the migratory final hosts, occurring in waters around the Pacific coast of Alaska. They play an important role in the transport of the north Pacific population of A. simplex (s.s.) into other regions of the Pacific and North Atlantic Ocean.

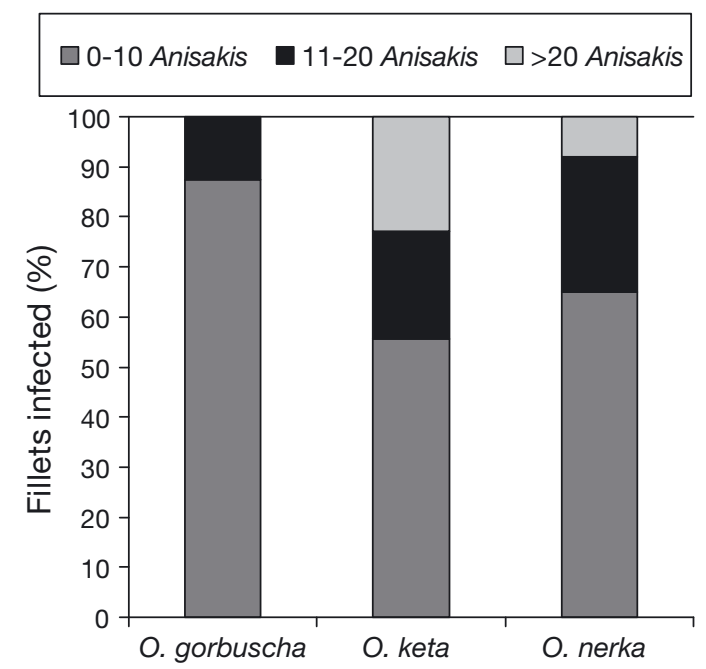

Fig. 3. Anisakis sp. infecting Oncorhynchus spp. Percentage of Pacific salmon fillets without belly flaps infected with $0-10$, 11-20 and > 20 nematodes $\mathrm{kg}^{-1}$ flesh

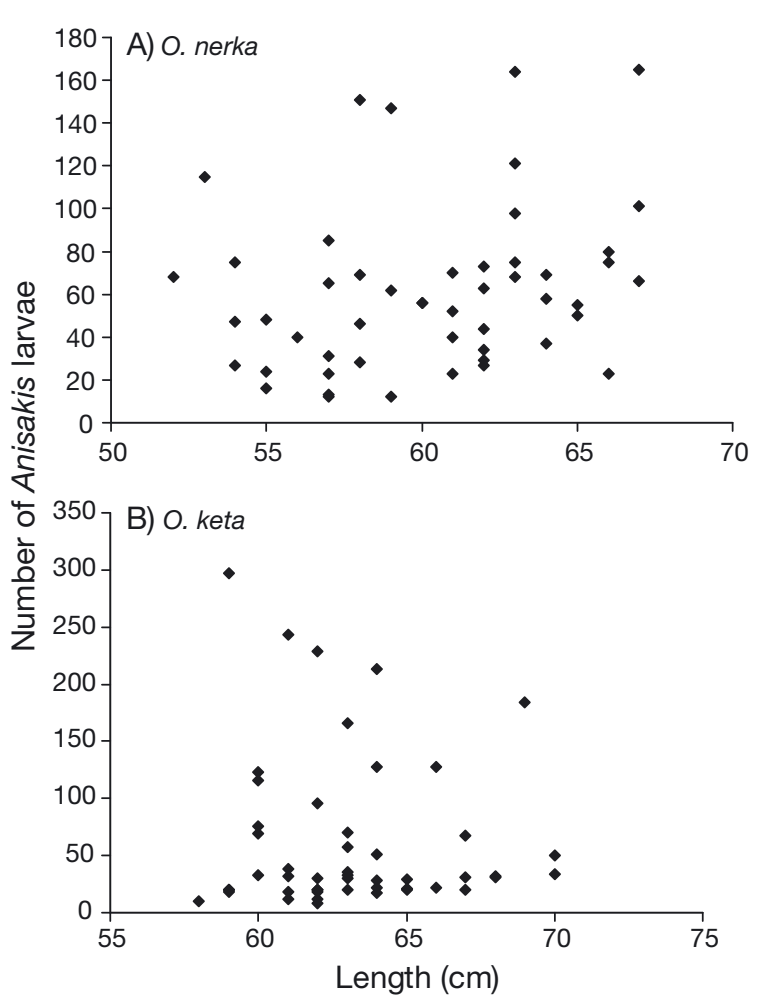

Fig. 4. Anisakis sp. infecting Oncorhynchus spp. Relationship between number of Anisakis larvae and fish total length in the edible part of (A) sockeye O. nerka and (B) chum salmon O. keta from Cordova, Alaska (USA)

\section{Comparison of different fishing grounds}

The intensity of Anisakis larvae was compared in fresh-caught Oncorhynchus nerka and O. keta salmon of commercial catches from the Bristol Bay area and from Cordova, respectively. In the Bristol Bay area, $O$. nerka samples were taken from the Nushagak and Naknek district and O. keta samples from the Nushagak district.

As most of the nematodes in Pacific salmon products on the German market have been detected in the belly flap area, only the hypaxial muscle was collected from salmon of Bristol Bay in this part of the investigation. It is known from other species that the distribution of Anisakis larvae within the same species does not vary much between different fishing grounds (Karl 2008). A comparison of the intensity in the belly flaps was therefore considered to be sufficient to estimate possible differences in infection levels in relation to the fishing ground.

The mean intensity of Anisakis larvae in the hypaxial muscle of Oncorhynchus nerka salmon was 3 times higher in the Bristol Bay area than in Prince William Sound close to Cordova (Table 4). On the other hand, there were no significant differences in the intensity of 
Table 4. Anisakis sp. infecting Oncorhynchus spp. Comparison of larvae in the hypaxial muscle (belly flaps) of sockeye (O. nerka) and chum salmon (O. keta) from different fishing grounds of Alaska (PWS: Prince William Sound). Intensity data are given as mean (range). Intensity values with different superscripts within a row are significantly different (Mann-Whitney rank sum test, $\mathrm{p} \leq 0.01$ )

\begin{tabular}{|lccc|}
\hline \multirow{2}{*}{$\begin{array}{l}\text { Infection } \\
\text { parameter }\end{array}$} & \multirow{2}{*}{ Cordova, PWS } & \multicolumn{2}{c|}{ Bristol Bay area -} \\
\cline { 3 - 4 } & & Naknek & Nushagak \\
\hline O. nerka & & & \\
Number of fish & 50 & 25 & 25 \\
Prevalence (\%) & 100 & 100 & 100 \\
Intensity & $53^{\mathrm{a}}(7-150)$ & $164^{\mathrm{b}}(43-311)$ & $157^{\mathrm{b}}(70-279)$ \\
$\begin{array}{l}\text { O. } \text { keta } \\
\text { Number of fish }\end{array}$ & 49 & & \\
$\begin{array}{l}\text { Prevalence (\%) } \\
\text { Intensity }\end{array}$ & 100 & & 100 \\
& $52^{\mathrm{a}}(7-244)$ & & $59^{\mathrm{a}}(5-285)$ \\
\hline
\end{tabular}

nematode larvae in O. keta salmon from both areas. The data indicate that the infection levels may vary between fishing grounds depending on the salmon species, but further studies are necessary to confirm these preliminary results.

\section{Post-mortem migration studies}

Previous studies on other fish species have shown rather controversial results concerning possible migration, and a hypothesis has been proposed that Anisakis larvae are only stimulated to migrate in 'fatty' fish species (Wharton et al. 1999). Alaskan salmon can be considered as more fatty than lean, and the purpose of this part of the study was to obtain more knowledge about possible post-mortem migration of Anisakis larvae from the viscera into the surrounding flesh of Alaskan salmon under commercial storage conditions either on ice or in RSW.

The storage of fresh-caught salmon in RSW for up to $24 \mathrm{~h}$ is normal practice which is applied widely on board the tenders receiving fish from small fishing boats during the salmon run seasons. Storage on wet ice was also tested, which is currently not viable due to the lack of ice manufacturing capacity in the US salmon industry. No tendency of post-mortem migration was observed from the viscera into the flesh, irrespective of the fish species and the storage conditions (Table 5). The results are not unexpected, considering the low abundance and intensity of Anisakis larvae in the viscera. The high number of nematodes in the muscle meat of fresh-caught Pacific salmon indicates that a migration into the flesh must occur either directly after intake of the nematodes via feeding or during earlier stages of the host life cycle.

\section{CONCLUSION}

One of the most important conclusions which can be drawn from this investigation is the fact that in maturing Oncorhynchus keta, O. keta and O. gorbuscha salmon from Alaska, Anisakis larvae (genetically identified as $A$. simplex s.s.) are more abundant in the musculature than in the viscera when returning from the open sea. More than $90 \%$ of the nematodes were found in the flesh, mainly in the hypaxial muscle. It appears that the infection level of the edible part depends on the fishing ground and the species, but further studies are required to get a more detailed picture of the infection intensities of Pacific salmon from the different commercial fishing areas of Alaska and

Table 5. Anisakis sp. infecting Oncorhynchus spp. Prevalence, intensity and abundance of larvae in the hypaxial muscle (belly flaps) and the viscera (without gonads) of Pacific salmon species in relation to the chilled storage conditions. Intensity and abundance data are given as mean (range). For the hypaxial muscle, no significant differences were found between storage methods within each species (Mann-Whitney rank sum test performed for each species, $\mathrm{p} \leq 0.01$ ). RSW: refrigerated sea water

\begin{tabular}{|c|c|c|c|c|c|c|}
\hline \multirow[t]{2}{*}{ Storage conditions } & \multirow{2}{*}{$\mathrm{n}$} & \multicolumn{2}{|c|}{ - Hypaxial muscle -} & \multicolumn{2}{|c|}{$\longrightarrow$ Viscera } & \multirow[b]{2}{*}{ Abundance } \\
\hline & & Prevalence $(\%)$ & Intensity & Prevalence (\%) & Intensity & \\
\hline \multicolumn{7}{|l|}{ O. keta } \\
\hline At capture & 49 & 100 & $52(7-244)$ & 74 & $2.8(1-16)$ & $2.1(0-16)$ \\
\hline $24 \mathrm{~h}$ ice & 23 & 100 & $49(6-267)$ & 91.4 & $5.2(0-25)$ & $5.7(1-25)$ \\
\hline $24 \mathrm{~h}$ RSW & 50 & 100 & $43(7-328)$ & 88 & $2.6(1-7)$ & $2.3(0-7)$ \\
\hline \multicolumn{7}{|l|}{ O. nerka } \\
\hline At capture & 50 & 100 & $52(7-150)$ & 72 & $3.0(1-32)$ & $2.2(0-32)$ \\
\hline $24 \mathrm{~h} \mathrm{ice}$ & 50 & 100 & $55(1-221)$ & 68 & $3.6(1-14)$ & $2.5(0-14)$ \\
\hline $24 \mathrm{~h}$ RSW & 50 & 100 & $56(8-160)$ & 80 & $2.9(1-14)$ & $2.3(0-14)$ \\
\hline \multicolumn{7}{|l|}{ O. gorbuscha } \\
\hline At capture & 12 & 100 & $18(4-38)$ & 67 & $3.1(1-5)$ & $2.1(0-5)$ \\
\hline $24 \mathrm{~h}$ ice & 14 & 100 & $13(2-25)$ & 64 & $2.0(1-5)$ & $1.3(0-5)$ \\
\hline
\end{tabular}


other countries. O. keta and O. nerka were more infected than O. gorbuscha. No migration of Anisakis larvae was observed from the viscera into the flesh during storage on ice or commercially in RSW storage for $24 \mathrm{~h}$.

A reduction of the nematode number in the flesh is possible by complete removal of the belly flaps, but this cannot guarantee fillets with an abundance of $<20$ nematode larvae $\mathrm{kg}^{-1}$. According to our data, more than $20 \%$ of Oncorhynchus keta and more than $8 \%$ of $O$. nerka fillets from the Prince William Sound close to Cordova exceeded the proposed limit.

Acknowledgements. We thank I. Bagge for skilful analysis of the samples. Parts of the present study were financially supported by the Bundesverband der Deutschen Fischindustrie und des Fischgroßhandels e.V., Hamburg, Germany, the Research and Innovation funds of the Heinrich Heine University Düsseldorf (no. 01020050 to S.K.) and the German Research Council (DFG KL 2087/1-1, 1-2).

\section{LITERATURE CITED}

Agersborg HPK (1918) Nematodes on marketable fishes. Science 48:493-495

Arthur JR, Margolis L, Whitaker DJ, McDonald TE (1982) A quantitative study of economically important parasites of walleye pollock (Theragra chalcogramma) from British Columbian waters and effects of post-mortem handling on their abundance in the musculature. Can J Fish Aquat Sci 39:710-726

Berland B (2003) Anisakis spp. In: Akuffo H, Linder E, Ljungström I, Wahlgreen M (eds) Parasites of the colder climates. Taylor \& Francis, London, p 161-168

Bush AO, Lafferty KD, Lotz JM, Shostak AW (1997) Parasitology meets ecology on its own terms: Margolis et al. revisited. J Parasitol 83:575-583

CODEX STAN 244 (2004) Standard for salted Atlantic herring and salted sprat. CODEX STAN 244-2004. Available at www.codexalimentarius.net/search/search.jsp

- Davey JT (1971) A revision of the genus Anisakis Dujardin, 1875 (Nematoda: Ascaridata). J Helminthol 45:51-72

$>$ Davey JT (1972) The incidence of Anisakis sp. larvae (Nematoda: Ascaridata) in commercially exploited stocks of herring (Clupea harengus L. 1758) (Pisces: Clupeidae) in British and adjacent waters. J Fish Biol 4:535-554

Deardorff TL, Kent ML (1989) Prevalence of larval Anisakis simplex in pen-reared and wild-caught salmon (Salmonidae) from Puget Sound, Washington. J Wildl Dis 25:416-419

Etzel V, Ramdohr S (2006) Bemerkungen zu Untersuchungsmethoden und Beurteilung von Nematodenlarven in Wildlachs. J Verbr Lebensm 1(Suppl 2):192

Etzel V, Boiselle C, Ramdohr S, Bartelt E (2007) Vorschlag zum Nachweis und zur Beurteilung von Nematodenlarven in Wildlachs vor dem Hintergrund des EU-Rechts. J Verbr Lebensm 2:496-498

Grabda J (1991) Marine fish parasitology. VCH-Verlag, Weinheim

Højgaard DP (1995) Whaleworm, Anisakis simplex, in the fillets of saithe, Pollachius virens, from Faroese waters. Frodskaparrit 43:107-113

Kahl W (1936) Über den Befall des Stintes mit Larven des Fadenwurms Porrocaecum decipiens. Fischmarkt 7: $177-181$
Karl H (2008) Nematode larvae in fish on the German market -20 years of consumer related research. Arch Lebensmittelhyg 59:107-116

Karl H, Leinemann M (1993) A fast and quantitative detection method for nematodes in fish fillets and fishery products. Arch Lebensmittelhyg 44:124-125

Karl H, Leinemann M (1995) Nematodenlarven in Heringen aus verschiedenen Fanggebieten. Inf Fischwirtsch 42: 89-94

Kellermanns E, Klimpel S, Palm HW (2007) Molecular identification of ascaridoid nematodes from the deep-sea onioneye grenadier (Macrourus berglax) from the East Greenland Sea. Deep-Sea Res I 54:2194-2202

- Klimpel S, Palm HW, Rückert S, Piatkowski U (2004) The life cycle of Anisakis simplex in the Norwegian Deep (northern North Sea). Parasitol Res 94:1-9

Klimpel S, Kellermanns E, Palm HW, Moravec F (2007) Zoogeography of fish parasites of the pearlside (Maurolicus muelleri), with genetic evidence of Anisakis simplex (s.s.) from the Mid-Atlantic Ridge. Mar Biol 152:725-732

Klimpel S, Kellermanns E, Palm HW (2008) The role of pelagic swarm fish (Myctophidae: Teleostei) in the oceanic life cylcle of Anisakis sibling species at the MidAtlantic Ridge, Central Atlantic. Parasitol Res 104:43-53

Klimpel S, Busch MW, Kuhn T, Rohde A, Palm HW (2010) The Anisakis simplex complex off the South Shetland Islands (Antarctica): endemic populations versus introduction through migratory hosts. Mar Ecol Prog Ser 403:1-11

Kuhn T (2010) Molecular studies on marine ascaridoid nematodes. MSc thesis, Heinrich Heine University, Düsseldorf

Levsen A, Lunestad BT (2010) Anisakis simplex third stage larvae in Norwegian spring spawning herring (Clupea harengus L.), with emphasis on larval distribution in the flesh. Vet Parasitol 171:247-253

Mattiucci S, Nascetti G (2008) Advances and trends in the molecular systematics of anisakid nematodes, with implications for their evolutionary ecology and host-parasite co-evolutionary processes. Adv Parasitol 66:47-148

Mattiucci S, Paoletti M, Damiano S, Nascetti G (2007) Molecular detection of sibling species in anisakid nematodes. Parassitologia 49:147-153

Mattiucci S, Paoletti M, Webb SC (2009) Anisakis nascettii n. sp. (Nematoda: Anisakidae) from beaked whales of the southern hemisphere: morphological description, genetic relationships between congeners and ecological data. Syst Parasitol 74:199-217

Priebe K (2007) Parasiten des Fischfilets. Springer-Verlag, Berlin

Roepstorff A, Karl H, Bloemsma B, Huss HH (1993) Catch handling and possible migration of Anisakis larvae in herring, Clupea harengus. J Food Prot 56:783-787

> Rózsa L, Reiczigel J, Majoros G (2000) Quantifying parasites in samples of hosts. J Parasitol 86:228-232

Smith JW (1984) The abundance of Anisakis simplex L3 in the body-cavity and flesh of marine teleosts. Int J Parasitol 14:491-495

Strømnes E, Andersen K (1998) Distribution of whaleworm (Anisakis simplex, Nematoda, Ascaridoidea) L3 larvae in three species of marine fish; saithe (Pollachius virens (L.), cod (Gadus morhua L.) and redfish (Sebastes marinus (L.) from Norwegian waters. Parasitol Res 84:281-285

Sugawara Y, Urawa S, Kaeriyama M (2004) Infection of Anisakis simplex (Nematoda: Anisakidae) larvae in chum salmon (Oncorhynchus keta) in the North Pacific Ocean, Bering Sea, and a river of Hokkaido. North Pacific Anadromous Fish Commission Doc 791. Hokkaido Tokai University, Sapporo 
Urawa S, Fujisaki Y (2006) Heavy infection of Anisakis simplex (Nematoda: Anisakidae) larvae in the muscle of maturing chum salmon: a preliminary report. North Pacific Anadromous Fish Commission Doc 993. National Salmon Resources Center, Fisheries Research Agency, Toyohira-ku

Valentini A, Mattiucci S, Bondanelli P, Webb SC, MignucciGiannone AA, Colom-Llavina MM, Nascetti G (2006) Genetic relationship among Anisakis species (Nematoda:

Editorial responsibility: Bernd Sures,

Essen, Germany
Anisakidae) inferred from mitochondrial cox2 sequences, and comparison with allozyme data. J Parasitol 92: 156-166

Wharton DA, Hassall ML, Aalders O (1999) Anisakis (Nematoda) in some New Zealand inshore fish. NZ J Mar Freshw Res 33:643-648

Zhu X, Gasser RB, Jacobs DE, Hung GC, Chilton NB (2000) Relationships among some ascaridoid nematodes based on ribosomal DNA sequence data. Parasitol Res 86: 738-744

Submitted: April 8, 2010; Accepted: November 30, 2010 Proofs received from author(s): March 17, 2011 